\title{
HERBAL MEDICINES AGAINST BACTERIAL VAGINOSIS IN WOMEN OF REPRODUCTIVE AGE: A SYSTEMATIC REVIEW
}

\author{
MONA NAJAF NAJAFI ${ }^{1 \#}$, RAMIN REZAEE ${ }^{1,6 \#}$, NESHAT NAJAF NAJAFI ${ }^{2}$, FIROOZEH \\ MIRZAEE $^{3}$, TATYANA I. BURYKINA ${ }^{4}$, DUMITRU LUPULIASA ${ }^{5}$, ANDREEA LETIȚIA \\ ARSENE $^{6}$, MASUMEH GHAZANFARPOUR $^{3 *}$ \\ ${ }^{1}$ Clinical Research Unit, Mashhad University of Medical Sciences, Mashhad, Iran \\ ${ }^{2}$ Students Research Committee, Mashhad University of Medical Sciences, Mashhad, Iran \\ ${ }^{3}$ Nursing Research Centre, Kerman University of Medical Sciences, Kerman, Iran \\ ${ }^{4}$ Department of Analytical and Forensic Medical Toxicology, Sechenov University, 119048, Moscow, Russian Federation \\ ${ }^{5}$ Pharmaceutical Technology and Biopharmacy Department, Faculty of Pharmacy, "Carol Davila” University of Medicine \\ and Pharmacy, 6 Traian Vuia Street, 020956, Bucharest, Romania \\ ${ }^{6}$ Department of General and Pharmaceutical Microbiology, Faculty of Pharmacy, "Carol Davila" University of Medicine \\ and Pharmacy, 6 Traian Vuia Street, 020956, Bucharest, Romania \\ ${ }^{6}$ Neurogenic Inflammation Research Centre, Mashhad University of Medical Sciences, Mashhad, Iran
}

*corresponding author: Masoumeh.Ghazanfarpour@yahoo.com

\#Authors with equal contribution

Manuscript received: August 2019

\begin{abstract}
The aim of this systematic review was to present the effect of herbal medicines on both clinical symptoms and laboratory findings of bacterial vaginosis in the reproductive age. Four major databases (PubMed, Scopus, ISI Web of Science, and Cochrane Library) were systematically searched for articles that evaluated the effect of herbal medicines on bacterial vaginosis and were published until July 31, 2019. Zataria multiflora was found to be as effective as oral or vaginal metronidazole in improvement of both clinical symptoms and laboratory parameters. However, it caused vaginal irritation and burning. The effect of garlic tablet was reported to be more marked than oral metronidazole in alleviating the clinical symptoms and comparable to that of oral metronidazole in improving laboratory findings. The effect of Nigella sativa was similar to metronidazole in treating both clinical symptoms and laboratory findings. Hypericum perforatum vaginal gel 3\% has proved to be as effective as metronidazole vaginal gel $0.75 \%$ in preventing bacterial vaginosis. Cure rate (recovery) in Myrtus communis L. plus metronidazole or Berberis vulgaris plus metronidazole was higher than that of metronidazole alone. Treatment with Hypercum perforatum for a week was very well tolerated, and caused no side effect. Herbal medicines including $H$. perforatum, $Z$. multiflora, B. vulgaris and Allium sativum was found to be as effective as metronidazole with a fewer side effect. Hence, they might be considered potential candidates to combat vaginosis.
\end{abstract}

\section{Rezumat}

Scopul acestui review a fost de a prezenta efectul produselor din plante atât asupra simptomelor clinice, cât și a rezultatelor de laborator în vaginoza bacteriană, la vârsta reproducerii. Patru baze de date majore (PubMed, Scopus, ISI Web of Science și Biblioteca Cochrane) au fost consultate sistematic privind studii care au evaluat efectul derivatelor din plante asupra vaginozei bacteriene și publicate până la 31 iulie 2019. Zataria multiflora s-a dovedit la fel de eficientă, pe cale orală sau vaginală, ca și metronidazolul în îmbunătățirea simptomelor clinice şi a parametrilor de laborator. Cu toate acestea, a provocat iritații și arsuri vaginale. Efectul extractelor de usturoi, administrate oral, a fost raportat a fi mai superior metronidazolului administrat oral. Efectul extractului de Nigella sativa a fost similar cu metronidazolul în tratarea atât a simptomelor clinice, cât și în normalizarea datelor de laborator de laborator. Hypericum perforatum gel vaginal 3\% s-a dovedit a fi la fel de eficient ca metronidazolul vaginal 0,75\%. Efectul asocierii extractelor de Myrtus communis L. sau Berberis vulgaris și metronidazol a fost mai superior comparativ cu metronidazolul administrat singur. Tratamentul cu Hypercum perforatum timp de o săptămână a fost foarte bine tolerat și nu a avut efecte secundare. Produsele din plante, inclusiv $H$. perforatum, Z. multiflora, B. vulgaris și Allium sativum s-au dovedit a fi cel puțin la fel de eficiente ca și metronidazolul, cu un efecte secundare mai puține.

Keywords: bacterial vaginosis, Gardnerella vaginalis, herbal medicine, medicinal plants, $H$. perforatum, $Z$. multiflora, $B$. vulgaris, Allium sativum, Nigella sativa

\section{Introduction}

Urogenital infections including urinary tract infections and yeast vaginitis affect the quality of life of the patients and impose a considerable burden on the healthcare system [1]. Approximately two-third of female's experience vaginitis at least once during their lifetime. It was reported that $90 \%$ of vaginitis cases 
are secondary to infections like bacterial vaginosis (BV), vaginal candidiasis, and Trichomonas vaginalis [2]. Bacterial vaginosis is associated with alteration of vaginal flora leading to a decrease in normal lactobacillus microflora and an increase in anaerobic bacteria, Gardnerella vaginalis, and Mycoplasma hominis. This infection may occur frequently in women of reproductive age. One of the BV clinical manifestations is vaginal discharge, mostly with a fishy odour, that is exacerbated usually after sexual intercourse [3]. The global prevalence of BV was estimated to vary between $22 \%$ and $50 \%$ with $20-49 \%$ in Africa, $11 \%$ in the UK and 15 - 30\% in the USA [4], as it is more prevalent in developing countries [3]. $\mathrm{BV}$ is the most frequent cause of vaginal discharge, observed in $22 \%$ to $50 \%$ of cases, and half of the infected women are asymptomatic [5]. BV can cause preterm labour, pelvic inflammatory disease and sexually transmitted diseases (STD) like human immune deficiency virus (AIDS) $[1,6,7]$.

Common antibiotics including clindamycin, metronidazole and tinidazole are wildly used for treatment of BV. But recurrence often occurs following the primary response to therapy [8].

Complications caused by chemical drugs have encouraged both patients and researchers to examine the efficacy and safety of probiotics $[9,10]$ or herbal medicines against various diseases including BV [11]. To the best of our knowledge, there is no systematic review presenting the effect of herbal medicines on BV. The present article reviews the herbal medicines that were shown to be effective on both clinical symptoms and laboratory findings in women of reproductive age who were diagnosed with BV.

\section{Materials and Methods}

The process of trials selection is shown in Figure 1. Main demographic and clinical characteristics of the patients as well as the methodologies of the trials included in the systematic review are shown in Table II.

\section{Search strategy}

Four major databases, PubMed, Scopus, Cochrane Library, and Web of Science, were checked during screening. The above-noted databases were systematically searched for studies that examined possible effects of herbal medicines on $\mathrm{BV}$ in females of reproductive age and were published until July 31, 2019. For this purpose, we used the following search string: ((bacterial vaginosis) OR (bacterial vaginitis) OR (bacterial vaginoses)) AND ((herbal medicine) OR (plant extract*) OR (medicinal plant*) OR (herb) OR (botany) OR (pharmacognosy) OR (phytotherapy) OR (naturopathy) OR (plant* medicinal) OR (herbal drug*) OR (herbal remedy) OR (herbal preparation*) OR (herbal product*) OR (herbal supplement*) OR (traditional medicine) OR (complementary medicine) OR (alternative medicine)).
Two reviewers independently screened all abstracts and full-text articles. Any discrepancies were resolved by discussion, and where no agreement was reached, an independent third-party was involved.

Inclusion criteria

All clinical trials were included in this systematic review if herbal medicines were orally or vaginally administrated as mono-therapy or in combination for treatment of $\mathrm{BV}$ in women of reproductive age (15 - 50 years old). There was no limit for the presence of a control group. Duplicates, non-English papers in vitro animal models, studies that reported co-infected by other pathogens like Candida spp. or Trichomonas vaginalis were excluded. The bibliography of the included trials was also thoroughly investigated. Quality assessment

The Jadad scale [12] was applied for assessing the quality of the included trials. Two authors independently examined the quality of papers. If there were discrepancies between the authors, it would be resolved by consensus or consultation with a third party. We also considered "intention-to-treat" analysis and "baseline comparability".

\section{Data extraction}

The general characteristics and information, including the first author, location of the study, date of study, patients age, type of intervention, the treatment that control group received, number of participants in each group, duration of treatment, dropout rate $(\%)$, results and side effects, were extracted. Data extraction was independently done by two authors.

\section{Results and discussion}

The initial search yielded 171 articles, of which, 56 duplicated articles were deleted. Out of the 115 remaining papers, 97 were excluded following assessment of the title and abstract. Eighteen full-text articles were further reviewed. We excluded 5 studies because patients were co-infected by other pathogens like Candida spp. or Trichomonas vaginalis. After fulltext review and verification, 13 papers were qualified for inclusion. Figure 1 demonstrates the search results and article selection process.

Quality assessment of the included studies is shown in Table I. All clinical trials were randomized and included a control group, but the randomization method was not mentioned in four papers. In one study, the randomization method was not correct. Blinding was not considered in 4 studies. All studies reported loss to follow-up. Only in one study, intentionto-treat analysis was done.

Detailed characteristics of the included studies are listed in Table II. All of the studies enrolled patients of reproductive age (i.e. 15 - 50 years old) and in all cases, the control group received different forms of metronidazole. Duration of intervention ranged from 5 to 7 days. 


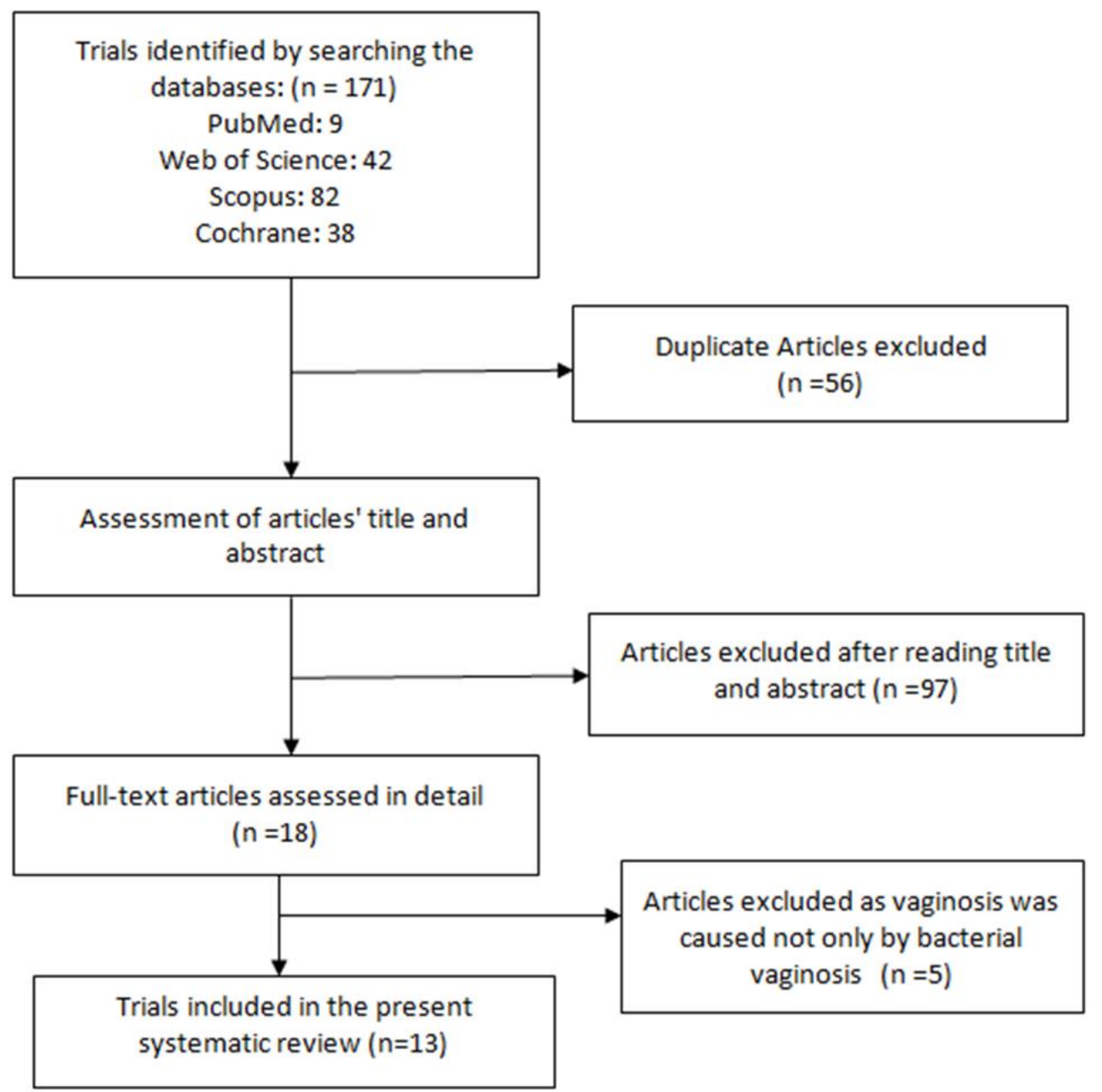

Figure 1.

The process of selection of the included trials

Table I

Quality assessment of the studies included in this systematic review

\begin{tabular}{|c|c|c|c|c|c|c|c|c|c|}
\hline \multirow[b]{2}{*}{ First author } & \multicolumn{3}{|c|}{ Randomization } & \multicolumn{3}{|c|}{ Blinding } & \multirow[b]{2}{*}{ 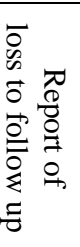 } & \multirow[b]{2}{*}{ 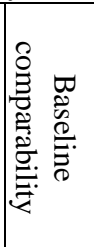 } & \multirow[b]{2}{*}{ 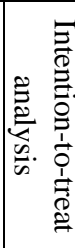 } \\
\hline & 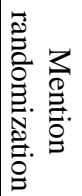 & 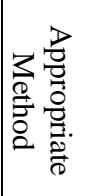 & 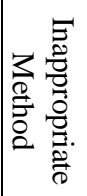 & 息 & 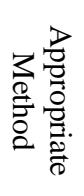 & 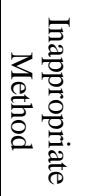 & & & \\
\hline Hafizi-Moori, M. [10] & + & $?$ & - & - & - & - & + & + & $?$ \\
\hline Azadpour Motlagh, A. [11] & + & + & - & + & + & - & + & + & - \\
\hline Leite, SRRF. [5] & + & + & - & + & + & - & + & + & + \\
\hline Baery, N. [12] & + & $?$ & - & + & + & - & + & + & $?$ \\
\hline Jafarnezhad, F. [13] & + & - & + & + & + & - & + & + & - \\
\hline Mohammadzadeh, F. [14] & + & + & - & + & + & - & + & + & - \\
\hline Masoudi, M. [15] & + & + & - & + & + & - & + & + & $?$ \\
\hline Simbar, M. [16] & + & $?$ & - & - & - & - & + & + & $?$ \\
\hline Abdali, K. [17] & + & + & - & + & + & - & + & + & $?$ \\
\hline Asadi, M. [18] & + & $?$ & - & - & - & - & + & + & $?$ \\
\hline Pazhohideh, Z. [19] & + & + & - & + & + & - & + & + & - \\
\hline Sosto, F. [20] & + & + & - & - & - & - & + & + & - \\
\hline Mohammad-Alizadeh-Charandabi, S. [8] & + & + & - & + & + & - & + & + & $?$ \\
\hline
\end{tabular}

"+" shows that the specific criteria was noted in the study; "“." indicates the absence of the criteria; "?" denotes that it was not possible to evaluate the specific criterion. 
Table II

Characteristic of the 13 trials included in this systematic review

\begin{tabular}{|c|c|c|c|c|c|c|c|c|}
\hline $\begin{array}{l}\text { First author, } \\
\text { country, year }\end{array}$ & $\begin{array}{c}\text { Patients age } \\
\text { range } \\
\text { (years old) }\end{array}$ & $\begin{array}{l}\text { Diagnosis } \\
\text { method }\end{array}$ & $\begin{array}{c}\text { Type of } \\
\text { intervention }\end{array}$ & $\begin{array}{l}\text { Control } \\
\text { group }\end{array}$ & $\begin{array}{c}\text { Duration } \\
\text { of } \\
\text { treatment }\end{array}$ & $\begin{array}{l}\text { Drop } \\
\text { out \% } \\
\text { (Int., } \\
\text { Con.) }\end{array}$ & Results & $\begin{array}{c}\text { Adverse event } \\
\text { in trial group } \\
(\%)\end{array}$ \\
\hline $\begin{array}{c}\text { Hafizi-Moori M, } \\
\text { 2010, Iran [13] }\end{array}$ & $18-44$ & \begin{tabular}{|c|} 
Patients' \\
complaints, \\
Amsel \\
clinical \\
criteria
\end{tabular} & \begin{tabular}{|} 
Micosin $^{\circledR}$ \\
vaginal cream \\
(made of \\
garlic) \\
$(\mathrm{n}=50)$
\end{tabular} & $\begin{array}{c}\text { Metronidazole } \\
\text { vaginal gel } \\
(\mathrm{n}=50)\end{array}$ & 7 days & $0 \%$ & $\begin{array}{c}\text { The two groups after } \\
\text { treatment had similar } \\
\text { results in terms of } \\
\text { improvement of } \\
\text { patients' complaints } \\
\text { and Amsel criteria } \\
\text { score }\end{array}$ & \begin{tabular}{|c|} 
Nausea $(18 \%)$ \\
Pruritus $(28 \%)$ \\
Drug-related \\
odour $(10 \%)$ \\
Irritation $(10 \%)$ \\
Vomiting $(6 \%)$ \\
Lower abdominal \\
pain $(4 \%)$ \\
Vertigo $(2 \%)$
\end{tabular} \\
\hline $\begin{array}{c}\text { Azadpour Motlagh } \\
\text { A, 2018, Iran [14] }\end{array}$ & $15-49$ & \begin{tabular}{|c|} 
Amsel \\
clinical \\
criteria, \\
Nugent \\
microscopic \\
criteria
\end{tabular} & \begin{tabular}{|c|} 
oral \\
metronidazole \\
+ Prangos \\
ferulacea \\
vaginal cream \\
$\quad(\mathrm{n}=50)$ \\
\end{tabular} & \begin{tabular}{|c|} 
Oral \\
metronidazole \\
+ placebo \\
vaginal cream \\
$\quad(\mathrm{n}=50)$ \\
\end{tabular} & 7 days & $\begin{array}{l}10 \% \\
10 \%\end{array}$ & $\begin{array}{c}\text { The two groups after } \\
\text { treatment had similar } \\
\text { results in terms of } \\
\text { patients' complaints, } \\
\text { Amsel clinical criteria } \\
\text { score and microscopic } \\
\text { criteria Nugnt }\end{array}$ & $\begin{array}{l}\text { Nausea, and } \\
\text { metallic taste } \\
\text { (Overall 16\%) }\end{array}$ \\
\hline $\begin{array}{c}\text { Leite SRRF, 2011, } \\
\text { Brazil [5] }\end{array}$ & $18-40$ & \begin{tabular}{|c|} 
Amsel \\
clinical \\
criteria, \\
Nugent \\
microscopic \\
criteria
\end{tabular} & $\begin{array}{c}\text { pepper tree } \\
\text { extract gel } \\
(n=137)\end{array}$ & $\begin{array}{c}\text { Metronidazole } \\
\text { gel } 0.75 \% \\
(\mathrm{n}=140)\end{array}$ & 7 days & $7 \%, 9 \%$ & \begin{tabular}{|c|} 
Total cure rate was \\
$12.4 \%$ in intervention \\
group and $56.4 \%$ in \\
control group \\
$(\mathrm{p}<0.001)$
\end{tabular} & $\begin{array}{c}\text { Heat }(307 \%) \\
\text { Rash }(0.7 \%) \\
\text { Itching }(3.7 \%) \\
\text { Burning }(3 \%) \\
\text { Abdominal pain } \\
(8.1 \%)\end{array}$ \\
\hline $\begin{array}{c}\text { Baery N, 2018, } \\
\text { Iran [15] }\end{array}$ & $18-50$ & $\begin{array}{l}\text { Amsel } \\
\text { clinical } \\
\text { criteria }\end{array}$ & \begin{tabular}{|c|} 
vaginal \\
suppository of \\
Forzejeh $^{\circledR}$ \\
(Tribulus \\
terrestris + \\
Myrtus \\
commnuis + \\
Foeniculum \\
vulgare + \\
Tamarindus \\
indica) \\
$(\mathrm{n}=64)$ \\
\end{tabular} & \begin{tabular}{|c|} 
Vaginal \\
suppository of \\
metronidazole \\
$\quad(n=63)$
\end{tabular} & 7 days & $\begin{array}{c}10 \% \\
9 \%\end{array}$ & \begin{tabular}{|c|} 
Fozejeh $^{\circledR}$ was as \\
effective as \\
metronidazole with \\
respect to the amount \\
and odour of \\
discharge, Amsel \\
criteria score, pelvic \\
pain and cervical \\
inflammation
\end{tabular} & $\begin{array}{c}\begin{array}{c}\text { No serious side } \\
\text { effect }\end{array} \\
\end{array}$ \\
\hline $\begin{array}{l}\text { Jafarnezhad F, } \\
\text { 2017, Iran [16] }\end{array}$ & $15-49$ & $\begin{array}{l}\text { Amsel } \\
\text { clinical } \\
\text { criteria }\end{array}$ & \begin{tabular}{|c|} 
Phytovagex $^{\circledR}$ \\
vaginal \\
suppository \\
$($ Nigella sativa $)$ \\
+ placebo tablet \\
$(\mathrm{n}=31)$ \\
\end{tabular} & \begin{tabular}{|} 
Metronidazole \\
oral tablet + \\
placebo \\
vaginal \\
suppository \\
$(\mathrm{n}=31)$ \\
\end{tabular} & 7 days & $\begin{array}{l}0 \%, \\
16 \%\end{array}$ & $\begin{array}{c}\text { Treatment success } \\
\text { rate was } 74.2 \% \text { for } \\
\text { Phytovagex and } 69.2 \% \\
\text { for metronidazole } \\
\text { group } \\
(\mathrm{p}=0.68) \\
\end{array}$ & $\begin{array}{l}\text { Mild burning } \\
(12.9 \%)\end{array}$ \\
\hline $\begin{array}{l}\text { Mohammadzadeh } \\
\text { F, 2014, Iran [17] }\end{array}$ & $18-44$ & \begin{tabular}{|c|} 
Amsel \\
clinical \\
criteria, \\
Nugent \\
microscopic \\
criteria
\end{tabular} & $\begin{array}{c}\text { Garlic tablet } \\
(\mathrm{n}=60)\end{array}$ & $\begin{array}{c}\text { Metronidazole } \\
\text { tablet } \\
(\mathrm{n}=60)\end{array}$ & 7 days & $\begin{array}{l}14 \% \\
14 \%\end{array}$ & $\begin{array}{l}\text { Treatment success in } \\
\text { garlic group }(63.3 \%) \\
\text { was higher than } \\
\text { metronidazole } \\
(48.3 \%) \text {, however, } \\
\text { non-significant } \\
(\mathrm{p}=0.141)\end{array}$ & $\begin{array}{l}\text { More frequent } \\
\text { side effects in } \\
\text { metronidazole } \\
\text { group than the } \\
\text { intervention } \\
\quad \text { group }\end{array}$ \\
\hline $\begin{array}{l}\text { Masoudi M, 2016, } \\
\text { Iran [18] }\end{array}$ & $18-40$ & $\begin{array}{l}\text { Amsel } \\
\text { clinical } \\
\text { criteria }\end{array}$ & \begin{tabular}{|c|} 
Vaginal gel \\
Berberis \\
vulgaris $5 \%$ \\
with metro- \\
nidazole base \\
(n = 40) and \\
Vaginal gel \\
Myrtus communis \\
$2 \%$ with \\
metronidazole \\
$(\mathrm{n}=40)$
\end{tabular} & $\begin{array}{c}\text { Metronidazole } \\
\text { vaginal gel } \\
0.75 \% \text { on } \\
\text { bacterial } \\
(\mathrm{n}=40)\end{array}$ & 5 days & $0 \%$ & \begin{tabular}{|c|} 
Cure rate in both \\
intervention groups \\
was higher than \\
metronidazole alone \\
$(\mathrm{p}<0.001)$ there was \\
no significant \\
difference between \\
to intervention \\
groups $(\mathrm{p}=0.18)$
\end{tabular} & Not mentioned \\
\hline $\begin{array}{c}\text { Simbar M, 2008, } \\
\text { Iran [19] }\end{array}$ & $18-40$ & \begin{tabular}{|c|} 
Amsel \\
clinical \\
criteria \\
Nugent \\
microscopic \\
criteria
\end{tabular} & $\begin{array}{c}\begin{array}{c}\text { Z. multiflora } \\
\text { vaginal cream } \\
(\mathrm{n}=45)\end{array} \\
\end{array}$ & $\begin{array}{c}\text { Metronidazole } \\
\text { vaginal gel } \\
(\mathrm{n}=45)\end{array}$ & 5 days & $4 \%, 2 \%$ & \begin{tabular}{|c|} 
There was no \\
significant difference \\
between intervention \\
and control groups \\
$(p>0.05)$
\end{tabular} & $\begin{array}{c}\text { Vaginal burning } \\
(14 \%)\end{array}$ \\
\hline
\end{tabular}


FARMACIA, 2019, Vol. 67, 6

\begin{tabular}{|c|c|c|c|c|c|c|c|c|}
\hline $\begin{array}{l}\text { First author, } \\
\text { country, year }\end{array}$ & $\begin{array}{c}\text { Patients age } \\
\text { range } \\
\text { (years old) }\end{array}$ & $\begin{array}{l}\text { Diagnosis } \\
\text { method }\end{array}$ & $\begin{array}{c}\text { Type of } \\
\text { intervention }\end{array}$ & $\begin{array}{l}\text { Control } \\
\text { group }\end{array}$ & $\begin{array}{c}\begin{array}{c}\text { Duration } \\
\text { of } \\
\text { treatment }\end{array} \\
\text { treatment }\end{array}$ & $\begin{array}{l}\text { Drop } \\
\text { out \% } \\
\text { (Int., } \\
\text { Con.) }\end{array}$ & Results & $\begin{array}{c}\text { Adverse event } \\
\text { in trial group } \\
(\%)\end{array}$ \\
\hline $\begin{array}{l}\text { Abdali K, 2015, } \\
\text { Iran [20] }\end{array}$ & $\begin{array}{c}\text { Reproductive } \\
\text { age }\end{array}$ & \begin{tabular}{|c|} 
Nugent \\
microscopic \\
criteria
\end{tabular} & $\begin{array}{l}\text { Z. multiflora } \\
\text { cream }+ \\
\text { placebo tablet } \\
\quad(\mathrm{n}=70)\end{array}$ & \begin{tabular}{|c|} 
Oral \\
metronidazole \\
tablet + \\
placebo cream \\
$(\mathrm{n}=70)$
\end{tabular} & 7 days & $0 \%$ & $\begin{array}{c}\text { There was no } \\
\text { significant difference } \\
\text { between intervention } \\
\text { and control groups } \\
(p>0.05)\end{array}$ & Irritation \\
\hline $\begin{array}{l}\text { Asadi M, 2016, } \\
\text { Iran [21] }\end{array}$ & $18-44$ & $\begin{array}{l}\text { Amsel } \\
\text { clinical } \\
\text { criteria }\end{array}$ & $\begin{array}{c}\text { Mycocin }^{\circledR} \\
\text { vaginal cream } \\
\left(\text { garlic }+^{+}\right. \\
\text {thyme }) \\
(\mathrm{n}=60)\end{array}$ & $\begin{array}{c}\text { Metronidazole } \\
\text { vaginal gel } \\
(\mathrm{n}=60)\end{array}$ & 7 days & $0 \%$ & $\begin{array}{c}\text { There was no } \\
\text { significant difference } \\
\text { between intervention } \\
\text { (86.66\% improvement) } \\
\text { and control groups } \\
(78.33 \% \text { improvement }) \\
(p>0.05)\end{array}$ & Not mentioned \\
\hline $\begin{array}{l}\text { Pazhohideh Z, } \\
\text { 2018, Iran [22] }\end{array}$ & $18-45$ & $\begin{array}{l}\text { Amsel } \\
\text { clinical } \\
\text { criteria }\end{array}$ & $\begin{array}{l}\text { Calendula } \\
\text { officinalis } \\
\text { cream } \\
(\mathrm{n}=40)\end{array}$ & $\begin{array}{l}\text { Metronidazole } \\
\text { vaginal cream } \\
\quad(\mathrm{n}=40)\end{array}$ & 7 days & $0 \%$ & $\begin{array}{l}\text { There was no } \\
\text { significant difference } \\
\text { between intervention } \\
\text { and control groups. } \\
\text { All patients cured }\end{array}$ & none \\
\hline $\begin{array}{l}\text { Sosto F, 2011, } \\
\text { Italy [23] }\end{array}$ & $\begin{array}{c}\text { Reproductive } \\
\text { age }\end{array}$ & $\begin{array}{l}\text { Amsel } \\
\text { clinical } \\
\text { criteria }\end{array}$ & $\begin{array}{c}\text { Thymol + } \\
\text { eugenol } \\
\text { vaginal } \\
\text { douche }\end{array}$ & $\begin{array}{l}\text { Metronidazole } \\
\text { suppository }\end{array}$ & 7 days & $\begin{array}{c}0.9 \% \\
\text { (overall) }\end{array}$ & $\begin{array}{c}\text { There was no } \\
\text { significant difference } \\
\text { between intervention } \\
\text { (86.66\% improvement) } \\
\text { and control groups } \\
(78.33 \% \text { improvement }) \\
(p>0.05)\end{array}$ & none \\
\hline $\begin{array}{l}\text { Mohammad- } \\
\text { Alizadeh- } \\
\text { Charandabi S, } \\
\text { 2014, Iran [11] }\end{array}$ & $18-49$ & $\begin{array}{l}\text { Amsel } \\
\text { clinical } \\
\text { criteria }\end{array}$ & $\begin{array}{l}\text { H. perforatum } \\
+ \text { placebo } \\
(\mathrm{n}=82)\end{array}$ & $\begin{array}{c}\text { Metronidazole } \\
+ \text { placebo } \\
(\mathrm{n}=80)\end{array}$ & 5 days & $0 \%$ & $\begin{array}{c}\text { There was no } \\
\text { significant difference } \\
\text { between intervention } \\
\text { ( } 82 \% \text { improvement) } \\
\text { and control groups } \\
\text { (85\% improvement) } \\
\text { (p=0.574) except } \\
\text { less itching in } \\
\text { intervention group } \\
(p=0.018)\end{array}$ & $\begin{array}{c}\text { Vaginal } \\
\text { irritation at first } \\
\text { day }(13 \%), \\
\text { nausea, } \\
\text { vomiting, } \\
\text { dizziness and } \\
\text { vaginal dryness }\end{array}$ \\
\hline
\end{tabular}

Int. = intervention; Con. $=$ Control

Effects of vaginal suppository of Foeniculum vulgare, Tribulus terrestris and Myrtus communis $v s$. metronidazole vaginal suppository

Baery et al. conducted a trial examining the effect of a vaginal suppository containing a combination of Foeniculum vulgare, Tribulus terrestris and Myrtus communis recommended by the Persian herbal medicine, in comparison to metronidazole, and found no difference in the amount of discharge $(p=0.33)$ and odour discharge $(p=0.18)$, Amsel's criteria, pelvic pain $(p=0.28)$ and cervical inflammation $(p=0.14)$ between the two treatments. However, significant differences were observed between the two groups concerning the presence of clue cells $(p<0.001)$, Gram-positive bacteria ( $\mathrm{p}<0.001), \mathrm{pH}(\mathrm{p}<0.001)$, Whiff test $(p<0.001)$ on the $14^{\text {th }}$ day of the trial. Comparison of data obtained before and after the trial showed a significant improvement in both clinical symptoms and laboratory parameters in both groups. However, no statistically significant difference was seen between the two groups regarding the clinical symptoms or the laboratory assessments after the trial period [15].

\section{Effects of pepper vaginal gel $v s$. metronidazole gel}

Brazilian women with BV were divided into two groups to receive either $0.75 \%$ metronidazole gel $(n=140)$ or pepper extract gel $(n=137)$. The cure rate based on Amsel's criteria, was $21.2 \%$ in women treated with pepper tree extract and $62.1 \%$ in women treated with metronidazole $(\mathrm{p}<0.001)$. The cure rate based on Nugent's score alone revealed that $13.9 \%$ were cured in the pepper tree extract group and $56.4 \%$ in the metronidazole group $(\mathrm{p}<0.001)$. Total cure (calculated using the two criteria) was $12.4 \%$ in the extract and $56.4 \%$ in the metronidazole group ( $<<0.001)$. Comparison of data obtained before and after the trial showed improvement for both clinical symptoms and laboratory parameters in both groups [5].

\section{Effects of Prangos ferulacea vaginal cream plus oral metronidazole $v s$. oral metronidazole}

One-hundred women with BV were randomized into two groups to receive oral metronidazole plus Prangos ferulacea vaginal cream (group A) or oral metronidazole plus a placebo (group B) vaginal cream for seven consecutive days. Comparison of data obtained before and after the treatment period, showed a significant 
improvement in patients' complaints (abundant discharge ( $\mathrm{p}<0.001)$ and malodour ( $<0.001)$, Amsel clinical criteria (gray homogeneous discharge $(\mathrm{p}<0.001)$, $\mathrm{pH}>4.5(\mathrm{p}<0.001)$, positive Whiff test $(\mathrm{p}<0.001)$, clue cell $20(\mathrm{p}<0.001))$ and microscopic criteria Nugent $(p<0.001)$. However, comparison between the two groups showed no significant difference regarding the mentioned parameters. $78 \%$ of women in group A and $30 \%$ of women in group B totally recovered by the end of the fourth day. Inter-group comparison showed a significant difference with further improvement in metronidazole combined with Prangos ferulacea group (A) [14].

\section{Effects of Zataria multiflora vaginal cream vs. metronidazole tablet/vaginal gel}

Two trials assessed the effect of $Z$. multiflora on BV. In the study performed by Simbar et al., the patients were randomly assigned into two groups of Z. multiflora vaginal cream and metronidazole vaginal gel. Complications such as vaginal discharge, amine odour, dyspareunia, hypogastric pain, coitus, dysuria and malodour, were relieved significantly in both groups except for itching in Z. multiflora group. Comparison of the two groups showed no significant differences in Amsel's criteria. The relative risk (RR) was 1.53, suggesting that both treatments had a comparable effect based on Amsel's criteria in the treatment of BV. The side effect of vaginal burning was higher in $Z$. multiflora group compared to the metronidazole group ( $\mathrm{p}<0.001)$ [19].

In the study performed by Abdali et al., the efficacy of vaginal $Z$. multiflora was compared with oral metronidazole tablet. Statistical comparison of the data obtained before and after the treatment revealed that Z. multiflora had a significantly better effect in terms of clinical symptoms, including foul-smelling discharge, itching, vaginal discharge and intercourse pain. However, there was no statistically significant difference in all clinical symptoms between $Z$. multiflora and metronidazole after the intervention period. Also, no statistically significant difference in Gram staining between the two groups was found. Side effects like metallic taste, nausea and dizziness were more frequent in metronidazole group, while the irritation was more common in Z. multiflora group [20].

\section{Effects of oral garlic $v s$. oral metronidazole}

Mohammadzadeh et al. randomized 120 women with BV, into two groups: garlic tablet and oral metronidazole. The clinical improvement, as evaluated based on the Amsel's criteria, was significantly higher in the garlic-treated group (70\%) compared to the metronidazole group $(48.3 \%)(\mathrm{p}<0.05)$. Improvement in laboratory parameters, as assessed based on Nugent criteria, was reported in $68.3 \%$ of the patients treated with garlic compared to $55 \%$ of subjects in metronidazole group ( $\mathrm{p}>0.05)$. Success rate was considered if both clinical and laboratory parameters improved. The treatment success rate in the garlic group (63.3\%) was higher than the metronidazole $(48.3 \%)$ group, although the difference was not statistically significant. Patients in the metronidazole group (33\%) reported side effect more frequently than the garlic group $(15 \%)(\mathrm{p}=0.032)$ [17].

In the second study, Hafizi-Moori et al. included 100 women with BV randomized into two groups that received Micosin ${ }^{\circledR}$ vaginal cream (containing garlic) or metronidazole vaginal gel. Comparison of data obtained before and after the treatment period, showed a significant decrease in patients' complaints and Amsel's clinical criteria score (gray homogeneous discharge $(\mathrm{p}<0.001), \mathrm{pH}<4.5(\mathrm{p}<0.001)$, positive Whiff test $(\mathrm{p}<0.001)$, clue cell $20(\mathrm{p}<0.001)$ ). However, comparison between the two groups showed no significant difference of the mentioned parameters. Response to treatment as assessed based on Amsel's clinical criteria, showed $80 \%$ improvement in Micosin and $70 \%$ improvement in metronidazole treated subjects $(\mathrm{p}<0.005)$ [13].

In Asadi et al. study, 120 women were randomly designated into two groups of 60 to receive Micosin ${ }^{\circledR}$ vaginal cream or metronidazole vaginal gel for 7 days. The patients' complaints and clinical Amsel's criteria score were improved in both groups after treatment. Also, the two groups were compared with respect to clinical Amsel's criteria and the patients' complaints, 7 days after completion of the treatment period; the results showed a decrease in the patients' complaints and clinical Amsel's criteria score in both groups. However, no significant difference was observed between the two groups in clinical improvement based on Amsel's criteria score [21].

\section{Effects of Hypericum perforatum L. vs. metronidazole}

Mohammad-Alizadeh-Charandabi et al. compared the effect of vaginal $H$. perforatum with vaginal metronidazole against BV. Odds ratio for malodour was 1.5 (95\% CI: 0.2 to $9 ; \mathrm{p}=0.873$ ), for burning 2.9 (95\% CI: 0.3 to $28.4 ; \mathrm{p}=0.371$ ), and for lower abdominal pain 1.1 (95\% CI: 0.4 to $3 ; \mathrm{p}=0.873$ ), indicating that the mean score for all the mentioned parameters in $H$. perforatum group was similar to that of the metronidazole group. However, odds ratio for itching was 0.3 (95\% CI: 0.1 to $0.8 ; p=0.026$ ) indicating that the mean frequency of itching was significantly lesser in the $H$. perforatum group than the metronidazole group. There was less frequent discharge in the $H$. perforatum group compared to the metronidazole group (4 vs. 15\%, $\mathrm{p}=0.013$ ). Also, the frequency of $\mathrm{pH}>4.5$ was higher in the $H$. perforatum group compared to the metronidazole group (60 vs. 36\%, respectively; $\mathrm{p}=0.003$ ). The BV recurrence was $9 \%$ in the $H$. perforatum group but 
FARMACIA, 2019, Vol. 67, 6

$13 \%$ in the metronidazole group $(\mathrm{p}=0.447)$. The $\mathrm{RR}$ for cure of $\mathrm{BV}(\mathrm{RR}=0.9$; $95 \% \mathrm{CI}$ : 0.6 to 1.3 ; $\mathrm{p}=0.574)$, presence of the clue cells $(\mathrm{RR}=1.3$; 95\% CI: 0.9 to $1.7 ; \mathrm{p}=0.153)$, and positive Whiff test $(\mathrm{RR}=0.8 ; 95 \% \mathrm{CI}: 0.4$ to $1.3 ; \mathrm{p}=0.31)$ suggested no statistically significant difference between $H$. perforatum and metronidazole. Satisfaction scores after treatment in the $H$. perforatum group and the metronidazole group were as follows: $67 \mathrm{vs.} 35 \%$ very satisfied, 19 vs. $33 \%$ satisfied, 11 vs. $13 \%$ unsure and 3 vs. 19\% unsatisfied [11].

\section{Effects of Nigella sativa vs. oral metronidazole}

Only one trial assessed the effect of $N$. sativa on BV. Jafarnezhad et al. randomized 57 patients with BV into two groups that received either Phytovagex ${ }^{\circledR}$ vaginal suppository $1 \%$ (containing $N$. sativa) once a day or $250 \mathrm{mg}$ oral metronidazole twice a day for a week. A statistically significant difference was seen between data obtained before and after treatment, in both groups in all Amsel's criteria scores (grey hemogenin discharge, clue cell in wet expansion, $\mathrm{pH} \leq 4.5$ and positive Whiff test), itching, burning, dyspareunia and inflammation. Intergroup comparison showed significant differences in all above-mentioned parameters. The treatment success was $74.2 \%$ for Phytovagex ${ }^{\circledR}$ and $69.2 \%$ for metronidazole $(\mathrm{p}>0.05)$ [16].

\section{Effects of Berberis vulgaris in metronidazole base, Myrtus communis $\mathrm{L}$. in metronidazole base and metronidazole alone}

Masoudi et al. compared three groups treated with $B$. vulgaris in metronidazole base, $M$. communis in metronidazole base and metronidazole alone; the study was done on 120 women (18 - 40 years old) with BV. Comparison of the three groups showed a statistically significant difference in the cure rate among the three groups $(\mathrm{p}<0.001)$. It was indicated that both $M$. communis in metronidazole base $(\mathrm{p}<0.001)$ and $B$. vulgaris in metronidazole base $(\mathrm{p}<0.001)$ were more efficacious than metronidazole alone. Comparison of the three groups showed no significant differences in terms of improvement of clinical symptoms of BV such as vaginal burning $(p=0.39)$, itching $(\mathrm{p}=0.48)$, redness $(\mathrm{p}=0.36)$, dyspareunia $(\mathrm{p}=0.10)$, ague $(\mathrm{p}=0.32)$, dysuria $(\mathrm{p}=0.78)$ and dysmenorrhea $(\mathrm{p}=0.90)$. No recurrence of infection occurred in Berberis vulgaris or Myrtus communis in metronidazole base groups while 12 patients $(30 \%)$ in the metronidazole group had reported infection recurrence during a three-week follow-up [18].

\section{Effects of Saugella lavanda Attiva vs. metronidazole} suppository

In Sosto et al. study, group A received thymol + eugenol vaginal douche once a day for seven days and group B received one metronidazole vaginal suppository once at night for one week plus econazole once at night for three days. The two groups were not different with respect to all symptoms including burning, vulvovaginal erythema, oedema, vaginal dryness, dyspareunia and vaginal discharge; however, itching was better controlled in B group in comparison to A group [23].

\section{Effects of Calendula officinalis vs. metronidazole vaginal cream}

A series of studies depict the complex role of Calendula officinalis and its bioactivity [42]. In Pazhohideh et al. study, women with BV were divided into two groups that received either methanolic extract of $C$. officinalis vaginal cream or metronidazole vaginal cream for seven days. All subjects in both groups were without symptoms 1 week after treatment completion [22].

Bacterial vaginosis is considered the most common vaginal infection [24]. Metronidazole, the first-line antibiotic to treat $\mathrm{BV}$, has shown a $70-80 \%$ success rate, but a $30 \%$ recurrence rate within three months, was reported [25]. Also, metronidazole is associated with several side effects including a metallic taste, nausea and transient neutropenia [15].

Clindamycin is the second choice in treatment of $\mathrm{BV}$ and has side effects such as abdominal cramps, colitis, nausea, vomiting, diarrhoea, and elevated liver enzymes [17]. Therefore, it is important to find novel agents for the treatment of BV. In this systematic review, we presented randomized controlled trials (RCTs) done to investigate the efficacy of application of herbal medicines in treatment of BV. Hence, we introduced 13 herbal medicines that were examined in this regard.

A suppository containing including Foeniculum vulgare, Tribulus terrestris and Myrtus communis, recommended by the Persian herbal medicine, was as effective as metronidazole suppository, regarding the amount of discharge. Pepper tree was more effective than placebo but less effective than metronidazole.

Z. multiflora was found to be as effective as oral or vaginal metronidazole against both clinical symptoms as well as laboratory parameters [20, 26]. The main components of $Z$. multiflora essential oil are thymol (22.3\%), followed by linalool (6.2\%), terpinene (6.4\%), 1,8-cineol (5.3\%), and carvacrol (3.1\%) [27]. Antibacterial and antifungal activities of thymol and carvacrol were reported in several studies [20].

Z. multiflora has shown the maximum level of antibacterial activity with the MICs of 0.625 and 
$1.25 \mathrm{mg} / \mathrm{mL}$ for Salmonella typhimurium and Listeria monocytogenes, respectively [28]. Ziaee et al. reported that the antibacterial activity Zataria multiflora Boiss. essential oil against Lactobacillus curvatus is mediated via affecting the membrane permeability and cell integrity [29].

In another trial [20], Z. multiflora and metronidazole caused a significant decrease of the clinical symptoms. In contrast to Abdali et al. study, improvement in itching symptom did not reach significant level in a study performed by Simbar et al. [26].

$H$. perforatum L. vaginal gel $3 \%$ was shown to be as effective as metronidazole vaginal gel $0.75 \%$ in preventing BV recurrence, and in treating this infection [11]. H. perforatum showed antibacterial [30-33], and anti-inflammatory activities in vitro $[25,34] . H$. perforatum alcoholic extracts (methanolic/ethanolic) were shown to be more effective than the aqueous extracts; also, Hypericum perforatum exhibits a lower antibacterial activity against Gram-negative bacteria than Gram-positive ones [35].

Nigella sativa effects against BV were comparable to those of metronidazole in alleviating both clinical symptoms and laboratory findings [16]. Nigella sativa is known for its antimicrobial activity [36], especially against anaerobic bacteria (Clostridium difficile, Clostridium perfringens, Bacteroides fragilis and Bacteroides thetaiotaomicron) [37] and Grampositive cocci (Staphylococcus aureus ATCC 25923 and Staphylococcus epidermidis CIP 106510) [38]. Moreover, garlic was found to be as effective as oral or vaginal metronidazole in improving both clinical and laboratory findings. Garlic has antimicrobial activities against both Gram-positive and Gram-negative microorganisms [39].

Crude extracts of garlic has antibacterial activity against methicillin-resistant Staphylococcus aureus (MRSA) strains [40] and standard strains of Escherichia coli and Staphylococcus aureus [39].

In Houshmand et al. trial, the extract of Myrtus communis showed different effects at different concentrations against aerobic and anaerobic bacteria [41]. Masoudi et al. reported that the antibacterial activity of $M$. communis is mediated through increased oxygen free radicals and lipid peroxidation, which can disrupt the bacterial cell wall.

According to other results, oral metronidazole plus oral Prangos ferulacea resulted in a faster improvement compared to metronidazole plus placebo [43]. However, it is not possible to precisely attribute the healing effects to one of the drugs in combination. Future studies are needed to examine the probable synergistic effects between metronidazole and herbal medicines.

\section{Limitations, strength and suggestions for future} research

There were some limitations in conducting the present review. Only one trial appropriately reported information on the intention-to-treat analysis [5].

For some trials [13, 15, 19, 21], it was not possible to evaluate the specific criteria for randomization and in one study [16] randomization was conducted inappropriately. Also, some trials [13, 19, 23] used no blinding method and in some studies, patients were not followed up to detect recurrence of their disease [14].

\section{Conclusions}

Herbs such as $H$. perforatum, Z. multiflora, $B$. vulgaris and garlic, were found to be as effective as metronidazole with fewer side effects. These findings must be interpreted with caution in light of the limitations of the above-noted trials like the low methodological quality. Health providers might prescribe these herbs to patients, especially those with metronidazole-resistant infections, and those who are sensitive towards the side effects of metronidazole.

\section{References}

1. Hantoushzadeh S, Golshahi F, Javadian P, Aram S, Hashemi S, Mirarmandehi B, Borna S, Comparative efficacy of probiotic yoghurt and clindamycin in treatment of bacterial vaginosis in pregnant women: A randomized clinical trial. J Matern-Fetal Neonat Med., 2012; 25(7): 1021-1024.

2. Peixoto F, Camargos A, Duarte G, Linhares I, Bahamondes L, Petracco A, Efficacy and tolerance of metronidazole and miconazole nitrate in treatment of vaginitis. Int J Gynecol Obstet., 2008; 102(3): 287-292.

3. Homayouni A, Bastani P, Ziyadi S, MohammadAlizadeh-Charandabi S, Ghalibaf M, Mortazavian AM, Mehrabany EV, Effects of probiotics on the recurrence of bacterial vaginosis: a review. J Lower Genit Tract Dis., 2014; 18(1): 79-86.

4. Khazaeian S, Navidian A, Navabi-Rigi SD, Araban M, Mojab F, Khazaeian S, Comparing the effect of sucrose gel and metronidazole gel in treatment of clinical symptoms of bacterial vaginosis: a randomized controlled trial. Trials, 2018; 19(1): 585: 1-8.

5. Leite SRRF, Amorim MMR, Sereno PFB, Leite TNF, Ferreira JAC, Ximenes RAA, Randomized clinical trial comparing the efficacy of the vaginal use of metronidazole with a Brazilian pepper tree (Schinus) extract for the treatment of bacterial vaginosis. Braz J Medic Biologic Res., 2011; 44(3): 245-252.

6. Sewankambo N, Gray RH, Wawer MJ, Paxton L, McNairn D, Wabwire-Mangen F, Serwadda D, Li C, Kiwanuka N, Hillier SL, Rabe L, Gaydos CA, Quinn TC, Konde-Lule J, HIV-1 infection associated with abnormal vaginal flora morphology and bacterial vaginosis. The Lancet, 1997; 350(9077): 546-550. 
7. Ayehunie S, Wang YY, Landry T, Bogojevic S, Cone RA, Hyperosmolal vaginal lubricants markedly reduce epithelial barrier properties in a threedimensional vaginal epithelium model. Toxicol Rep., 2018; 5: 134-140.

8. Baery N, Amin G, Amin M, Mokaberinejad R, Momtaz S, Nejad AG, Anushiravani M, Gharazi Z, Adhami $S$, Herbal remedies used in treatment of bacterial vaginitis: A mini-review. Indo Am J Pharmaceutic Sci., 2017; 4(11): 3830-3839.

9. Lakshmi SG, Jayanthi N, Saravanan M, Ratna MS, Safety assesment of Bacillus clausii UBBC07, a spore forming probiotic. Toxicol Rep., 2017; 4: 62-71.

10. Sabbatini S, Monari C, Ballet N, Mosci P, Decherf AC, Pélerin F, Perito S, Scarpelli P, Vecchiarelli A, Saccharomyces cerevisiae-based probiotic as novel anti-microbial agent for therapy of bacterial vaginosis. Virulence, 2018; 9(1): 954-966.

11. Mohammad-Alizadeh-Charandabi S, Mohammadzadeh Z, Farshbaf-Khalili A, Javadzadeh Y, Effect of Hypericum perforatum L. compared with metronidazole in bacterial vaginosis: a double-blind randomized trial. As Pac J Trop Biomed., 2014; 4(11): 896-902.

12. Jadad AR, Moore RA, Carroll D, Jenkinson C, Reynolds DJ, Gavaghan DJ, McQuay HJ, Assessing the quality of reports of randomized clinical trials: is blinding necessary?. Control Clin Trials, 1996; 17(1): $1-12$.

13. Hafizi-Moori M, Dolatian M, Naghash A, Moatar $\mathrm{F}$, Alavi-Majd $\mathrm{H}$, The comparison of the effects of micosin vaginal cream (made of garlic) and metronidazole vaginal gel on treatment of bacterial vaginosis. Arak Med Univ J., 2010; 13(3): 35-44.

14. Azadpour Motlagh A, Dolatian M, Mojab F, Nasiri M, Ezatpour B, Sahranavard Y, Shakiba H, Rahimy B, Ghanati K, The effect of Prangos ferulacea vaginal cream on accelerating the recovery of bacterial vaginosis: A randomized controlled clinical trial. Int J Community Based Nurs Midwif., 2018; 6(2): 101-110.

15. Baery N, Ghasemi Nejad A, Amin M, Mahroozade S, Mokaberinejad R, Bioos S, Anushiravani M, Aliasl J, Karimi Darmiyan M, Amin G, Effect of vaginal suppository on bacterial vaginitis based on Persian medicine (Iranian traditional medicine): a randomised double blind clinical study. J Obst Gynaec: J Instit Obst Gynaec., 2018; 38(8): 1110-1114.

16. Jafarnezhad F, Kiyani Mask M, Rakhshandeh H, Taghi Shakeri M, Comparison of the percentage of medical success for Phytovagex vaginal suppository and Metronidazole oral tablet in women with bacterial vaginosis. Iran J Obstet Gynec Infert., 2017; 20(3): 29-39.

17. Mohammadzadeh F, Dolatian M, Jorjani M, Majd HA, Borumandnia N, Comparing the Therapeutic Effects of Garlic Tablet and Oral Metronidazole on Bacterial Vaginosis: A Randomized Controlled Clinical Trial. Iran Red Cresc Med J., 2014; 16(7): e19118: 1-6.

18. Masoudi M, Miraj S, Rafieian-Kopaei M, Comparison of the Effects of Myrtus Communis L, Berberis Vulgaris and Metronidazole Vaginal Gel alone for the Treatment of Bacterial Vaginosis. J Clin Diag Res., 2016; 10(3): QC4-QC7: 1-4.
19. Simbar M, Azarbad Z, Moiab F, Majd HA, A comparative study of the therapeutic effects of the Zataria multiflora vaginal cream and metronidazole vaginal gel on bacterial vaginosis. Phytomedicine, 2008; 15(12): 1025-1031.

20. Abdali K, Jahed L, Amooee S, Zarshenas M, Tabatabaee $\mathrm{H}$, Bekhradi R, Comparison of the effect of vaginal Zataria multiflora cream and oral metronidazole pill on results of treatments for vaginal infections including trichomoniasis and bacterial vaginosis in women of reproductive age. BioMed Res Int., 2015; 2015: 683640: 1-7.

21. Asadi M, Forouhari S, Jahromi BN, Zarei A, Sayadi M, Rad SK, Comparison of the effects of Mycocin vaginal cream and Metronidazole vaginal gel on treatment of bacterial vaginosis: A randomized clinical trial. Int J Med Res Health Sci., 2016; 5(8): 250-256.

22. Pazhohideh Z, Mohammadi S, Bahrami N, Mojab F, Abedi P, Maraghi E, The effect of Calendula officinalis versus metronidazole on bacterial vaginosis in women: A double-blind randomized controlled trial. J Adv Pharmaceut Tech Res., 2018; 9(1): 15-19.

23. Sosto F, Benvenuti C, Controlled study on thymol + eugenol vaginal douche versus econazole in vaginal candidiasis and metronidazole in bacterial vaginosis. Arzneimittel-Forschung/Drug Res., 2011; 61(2): 126-131.

24. Wiesenfeld HC, Hillier SL, Krohn MA, Amortegui AJ, Heine RP, Landers DV, Sweet RL, Lower genital tract infection and endometritis: insight into subclinical pelvic inflammatory disease. Obstet Gynecol., 2002; 100(3): 456-463.

25. Paterniti I, Briguglio E, Mazzon E, Galuppo M, Oteri G, Cordasco G, Cuzzocrea S, Effects of Hypericum Perforatum, in a rodent model of periodontitis. BMC Compl Alt Med., 2010; 10(1): 73: 1-10.

26. Simbar M, Azarbad Z, Mojab F, Majd HA, A comparative study of the therapeutic effects of the Zataria multiflora vaginal cream and metronidazole vaginal gel on bacterial vaginosis. Phytomedicine, 2008; 15(12): 1025-1031.

27. Hamdieh M, Hosseini S, Lotfollahian H, Mohiti AM, Gholami KA, Effect of thyme (Zataria multiflora Boiss) essential oil on performance, carcass characteristics, and meat oxidative stability of broilers. Anim Prod Res., 2013; 2(2); 43-53.

28. Mojaddar Langroodi A, Tajik H, Mehdizadeh T, Antibacterial and Antioxidant Characteristics of Zataria multiflora Boiss Essential Oil and Hydroalcoholic Extract of Rhus coriaria L. J Food Qual Haz Contr., 2019; 6(1): 16-24.

29. Ziaee E, Razmjooei M, Shad E, Eskandari MH, Antibacterial mechanisms of Zataria multiflora Boiss. essential oil against Lactobacillus curvatus. LWT, 2018; 87: 406-412.

30. Milosevic T, Solujic-Sukdolak S, Sukdolak S, In vitro study of ethanolic extract of Hypericum perforatum L. on growth and sporulation of some bacteria and fungi. Turk J Biol., 2007; 31(4): 237-241.

31. Feyzioğlu B, Demircili ME, Doğan M, Baykan M, Antibacterial effect of hypericin. Afr J Microbiol Res., 2013; 7(11): 979-982.

32. Nawchoo IA, In vitro antibacterial activity and phytochemical studies of methanolic extract of 
leaves of Hypericum perforatum L. growing wild in Kashmir Himalaya. As J Plant Sci Res., 2012; 2(4): 414-420.

33. Alireza M, Antimicrobial activity and chemical composition of essential oils of chamomile from Neyshabur, Iran. J Med Plants Res., 2012; 6(5): 820-824.

34. Zdunić G, Gođevac D, Milenković M, Vučićević D, Šavikin K, Menković N, Petrović S, Evaluation of Hypericum perforatum oil extracts for an antiinflammatory and gastroprotective activity in rats. Phytother Res., 2009; 23(11): 1559-1564.

35. Saddiqe Z, Naeem I, Maimoona A, A review of the antibacterial activity of Hypericum perforatum L. J Ethnopharmac., 2010; 131(3): 511-521.

36. Georgescu M, Tăpăloagă PR, Tăpăloagă D, Furnaris F, Ginghină O, Negrei C, Giuglea C, Bălălău C, Ștefănescu E, Popescu IA, Georgescu D, Evaluation of antimicrobial potential of Nigella sativa oil in a model food matrix. Farmacia. 2018; 66(6): 10281036.

37. Chaieb K, Kouidhi B, Jrah H, Mahdouani K, Bakhrouf A, Antibacterial activity of Thymoquinone, an active principle of Nigella sativa and its potency to prevent bacterial biofilm formation. BMC Compl Alt Med., 2011; 11(1): 29: 1-6.

38. Randhawa MA, Alenazy AK, Alrowaili MG, Basha J, An active principle of Nigella sativa L., thymo- quinone, showing significant antimicrobial activity against anaerobic bacteria. J Intercult Ethnopharmac., 2017; 6(1): 97-101.

39. Saxena G, Sadawarte K, Kaore NM, Antibacterial activity of aqueous extract of garlic (Allium sativum) on standard strains. J Evol Med Dent Sci-JEMDS., 2018; 7(19): 2320-2322.

40. Ain NU, Riaz S, Abrar S, Ahmad M, Khan Z, Hafiz S, Hussain S, Hayat Haider M, Horizontal gene transfer and antibacterial effect of Allium sativum (garlic) on methicillin-resistant Staphylococcus aureus. Ann Pak Inst Med Sci., 2017; 13-2: 186-190.

41. Houshmand B, Mortazavi H, Alikhani Y, Abdolsamadi HR, Ahmadi Motemayel F, Zare Mahmoudabadi R, In vitro evaluation of antibacterial effect of Myrtus extract with different concentrations on some oral bacteria. J Mashad Dent Sch., 2011; 35(2): 123-130.

42. Olennikov DN, Kashchenko NI, Vennos C, A new esculetin glycoside from Calendula officinalis (Asteraceae) and its bioactivity. Farmacia, 2017; 65(5): 698-702.

43. Motlagh AA, Dolatian M, Mojab F, Nasiri M, Ezatpour B, Sahranavard Y, Shakiba H, Rahimy B, Ghanati K, The effect of Prangos ferulacea vaginal cream on accelerating the recovery of bacterial vaginosis: a randomized controlled clinical trial. Int J Community Based Nurs Midwif., 2018; 6(2): 100-110. 